\title{
Dampak Bantuan Langsung Tunai (BLT) Dana Desa Terhadap Kesejahteraan Masyarakat Desa Oi Tui Pada Masa Pandemi Covid-19 di Tinjau Dari Perspektif Ekonomi Syariah
}

\author{
Taman Firdaus ${ }^{1 *}$, Rafiuddin ${ }^{2}$, Mukrabin $^{3}$ \\ 1,2,3) Institut Agama Islam Muhammadiyah Bima \\ *Corresponding Author:f.taman82@gmail.com
}

\begin{abstract}
ABSTRAK - Penelitian ini menggunakan metode kualitatif deskriptif. Data dikumpulkan dengan teknik observasi, wawancara, dan dokumentasi. Adapun sumber data dalam penelitian ini yaitu sumber data primer dan data sekunder. Tujuannya adalah untuk mengetahui dampak Bantuan Langsung Tunai (BLT) dana desa terhadap kesejahteraan masyarakat Desa Oi Tui pada masa pandemic COVID-19, dan untuk mengetahui peran pemerintah desa dalam pelaksanaan program BLT di Desa Oi Tui. Berdasarkan hasil penelitian bahwa jumlah keluarga penerima manfaat BLT dana desa di Desa Oi Tui yaitu sebanyak 60 KPM. BLT Dana desa memang tidak secara langsung berdampak pada meningkatnya kesejahteraan masyarakat miskin di Desa Oi Tui, karena jumlah uang yang diterima dinilai kecil. Penggunaan uang tersebut memang dipakai untuk memenuhi kebutuhan mendasar. Pemerintah Desa Oi Tui dalam menyalurkan BLT Dana desa sudah sesuai dengan regulasi dari pemerintah pusat walaupun ada beberapa non tekhnis.
\end{abstract}

Kata Kunci - Dampak; BLT Dana desa; Ekonomi Syariah.

\section{PENDAHULUAN}

Pada tanggal 2 Maret Indonesia telah melaporkan 2 kasus COVID-19 dan manyatakan COVID-19 sebagai bencana non alam berupa wabah penyakit yang wajib dilakukan upaya penanggulangan. Untuk menangani pandemi COVID-19, pemerintah telah menetapkan berbagai kebijakan antara lain: penetapan Pembatasan Sosial Berskala Besar (PSBB), penetapan gugus tugas percepatan penanganan COVID19, karantina, isolasi, karantina rumah, karantina rumah sakit, dan karantina wilayah. ${ }^{1}$

Dampak sosial dan ekonomi yang di akibatkan pandemi COVID-19 sangat berpengaruh bagi tingkat kesejahteraan masyarakat. Hal ini disebabkan adanya pembatasan kegiatan Ekonomi yang secara makro menurunkan pertumbuhan Ekonomi, yang menyebabkan banyak orang kehilangan pekerjaan, sehingga berpotensi meningkatkan jumlah masyarakat miskin. Dalam rangka melindungi masyarakat miskin, pemerintah memperluas Jaring Pengaman

1Carly Erfly Fernando Maun."Efektivitas Bantuan Langsung Tunai Dana desa bagi Masyarakat Miskin Terkena Dampak Covid-19 Di Desa Talaitad Kecamatan SuluunTaretan Kabupaten Minahasa Selatan".Jurnal politic,.No. 9., volume 2 (2020), 1-2. 
Sosial (JPS) termasuk yang tertuang dalam peraturan menteri desa PDTT nomor 6 tahun 2020 tentang perubahan peraturan Menteri desa PDTT nomor 11 tahun 2019 tentang prioritas penggunaan dana desa, yang diantaranya terkait penyediaan bantuan langsung tunai yang bersumber dari dana desa. ${ }^{2}$

Intruksi Menteri dalam Negeri nomor 3 tahun 2020 tentang penanggulangan COVID 19 di Desa melalui anggaran pendapatan dan belanja desa, dan peraturan menteri keuangan nomor 40 tahun 2020 tentang perubahan atas peraturan menteri keuangan nomor 205 tahun 2019 tentang pengelolaan dana desa. dengan adanya desakan ekonomi, maka BLT-Dana desaharus dilaksanakan secara cepat dan tepat sasaran sehingga perlu didukung data yang valid dan akurat. ${ }^{3}$

Ada beberapa program jaminan perlindungan sosial pada saat pandemi, salah satunya adalah Bantuan Langsung Tunai (BLT) dana desa. Calon penerima BLT- dana desa adalah masyarakat miskin dan rentan yang belum menerima bantuan dari skema jaminan kesejahteraan sosial lain, seperti: Bantuan Sosial Tunai (BST), Program Keluarga Harapan (PKH), Bantuan Pangan Non-Tunai (BPNT), dan bantuan sosial lain yang diberikan oleh pemerintah, baik yang terdata dalam data terpadu kesejahteraan sosial (DTKS), maupun yang tidak terdata (exclusion error) yang memenuhi kriteria. Desa dapat menentukan sendiri siapa calon penerima BLT- dana desa selama mengikuti kriteria yang ditetapkan, melaksanakan pendataan secara transparan dan adil serta dapat dipertanggung jawabkan secara hukum. Desa dapat menggunakan data desa sebagai acuan, serta menggunakan data terpadu kesejahteraan sosial (DTKS) sebagai referensi penerima Program Keluarga Harapan (PKH), Bantuan Pangan Non Tunai (BPNT), serta data dinas ketenagakerjaan untuk identifikasi penerima bantuan prakerja, jika data penerima Jaring Pengaman Sosial (JPS) tersebut tidak tersedia, maka desa bisa menggunakan Data rekapitulasi penerima bantuan dari pendamping program Jaring Pengaman Sosial. ${ }^{4}$

\section{TINJAUAN PUSTAKA}

\section{Bantuan Langsung Tunai (Blt) Dana Desa \\ Pengertian Bantuan Langsung Tunai Dana desa}

Dalam pasal 1 angka 28 peraturan menteri desa PDTT no.6 tahun 2020 tentang perubahan atas peraturan menteri desa PDTT nomor 11 Tahun 2019 tentang perioritas penggunaan dana desa tahun 2020 dijelaskan tentang Bantuan langsung tunai dana desa yang disingkat BLT-Dana desa, adalah pemberian

2 Rudi S. prawiradinata, panduan pendataan bantuan langsung tunai dana desa (BLT dana desa), (Jakarta: Kementerian Desa,pembangunan Daerah Tertinggal Dan Transmigrasi,2020), 1.

3Ibid, 2

Ilbid, 3 
uang tunai kepada keluarga yang tidak mampu atau miskin di desa untuk meringankan beban perekonomian sebagai imbas akibat pandemi COVID-19.5

\section{Tujuan Bantuan Langsung Tunai (BLT) Dana Desa}

Bantuan Langsung Tunai merupakan bagian dari jaring pengaman social, maka tujuan dari bantuan langsung tunai dana desa yaitu menjaga daya beli masyarakat desa di tengah merosotnya perekonomian nasional karena pandemi COVID-19, membantu masyarakat desa yang miskin dan tidak mampu supaya tetap bertahan hidup dan memenuhi kebutuhan sehari-harinya dan juga masyarakat desa yang terkena PHK dan menderita penyakit kronis. ${ }^{6}$

\section{Kriteria Penerima BLT- Dana Desa}

Pemberian BLT-Dana Desa ditujukan untuk keluarga miskin dan rentan yang memenuhi kriteria serta belum menerima PKH, BPNT, dan kartu prakerja. Penetapan data keluarga miskin baru di desa diputuskan bersama dalam musdeusus. Musdeusus juga dapat membahas pemilihan target sasaran dan jenis program bantuan yang diberikan agar tidak terjadi tumpang tindih target sasaran program bantuan sosial. Penetapan keluarga miskin penerima BLT-Dana Desa ini dilaksanakan melalui pendekatan yang memperkuat modal sosial masyarakat yaitu musyawarah dan gotong royong.

\section{Mekanisme Pendataan penerima Manfaat BLT-Dana Desa}

Pendataan dilakukan oleh relawan desa lawan COVID-19 yang terdiri dari Kepala Desa sebagai ketua, ketua BPD sebagai wakil ketua, kemudian anggota yang terdiri dari perangkat desa, sekretaris desa, ketua RT, RW, tokoh agama, tokoh masyarakat, tokoh adat, tokoh pemuda, dan tokoh perempuan. ${ }^{7}$

\section{Kesejahteraan Masyarakat}

\section{Pengertian Kesejahteraan Masyarakat}

Kesejahteraan adalah rasa tentram seseorang karena terpenuhinya hajathajat hidup lahir dan batin. Kesejahteraan lahir didasarkan pada standar universal menyangkut kesehatan, sandang, pangan, dan papan. Sedangkan kesejahteraan batin menyangkut persepsi yang bersifatintelektual, emosional

\footnotetext{
5Fatkhul Khoiriyah dkk," Efektivitas pelaksanaan bantuan sosial dari pemerintah terhadapmasyarakatterdampak covid 19di desa gendongarum kecamatan kanorkabupaten bojonegoro,"spirit public, no.2volume 15, (2020), 101.

${ }^{6}$ Ibid

${ }^{7}$ Ibid
}

J-ESA (Jurnal Ekonomi Syariah) 
maupun spiritual seseorang. Kesejahteraan bukan alat perjuangan tapi tujuan perjuangan. ${ }^{8}$

Kesejahteraan merupakan suatu keadaan yang menunjukan bahwa masyarakat sejahtera dengan terpenuhinya kebutuhan secara materil dan sosial. Berbicara kesejahteraan akan berkaitan dengan konteks kemiskinan, namun tidak dalam semua hal. Semakin tinggi tingkat kesejahteraan hidup masyarakat maka semakin rendah kemiskinan. Semakin tinggi angka kemiskinan yang terjadi semakin banyak masyarakat yang tidak sejahtera. ${ }^{9}$

Menurut Imam Al-Ghazali, kegiatan ekonomi sudah menjadi bagian dari kewajiban sosial masyarakat yang telah ditetapkan oleh Allah SWT, jika hal itu tidak dipenuhi, maka kehidupan dunia akan rusak dan kehidupan umat manusia akan binasa. Selain itu, Al-Ghazali juga merumuskan tiga alasan mengapa seseorang harus melakukan aktivitas ekonomi, yaitu: Pertama, untuk memenuhi kebutuhan hidup masing-masing. Kedua, untuk menciptakan kesejahteraan bagi dirinya dan keluarganya dan ketiga, untuk membantu orang lain yang sedang membutuhkan.

Al-Qur'an telah menyinggung indikator kesejahteraan dalam surat Quraisy ayat $3-4^{\prime \prime}$

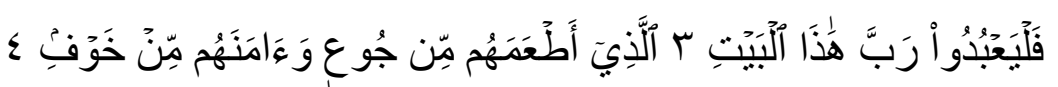

Terjemahan: Maka hendaklah mereka menyembah tuhan pemilik rumah ini (ka'bah). yang telah memberikan makanan kepada mereka untuk menghilangkan lapar dan mengamankan mereka dari rasa takut"

Berdasarkan ayat di atas, maka kita dapat melihat bahwa indikator kesejahteraan dalam Al-Qur'an ada tiga, yaitu menyembah tuhan (pemilik) Ka'bah, menghilangkan lapar dan menghilangkan rasa takut. ${ }^{10}$

\section{Masyarakat}

Masyarakat adalah pergaulan hidup manusia, sehimpunan manusia yang hidup bersama dalam suatu tempat dengan ikatan-ikatan aturan yang tertentu, orang banyak khalayak ramai. Sedangkan Horton dan Hunn mendefinisikan masyarakat sebagai sekumpulan manusia yang secara relative mandiri, yang hidup bersama-sama cukup lama, yang mendiami suatu wilayah mandiri, memiliki kebudayaan yang sama, dan melakukan sebagian besar kegiatannya dalam kelompok tersebut. ${ }^{11}$

\footnotetext{
8 Syekh nurjati," peranan pemerintahdalammensejahterakanmasyarakat melalui bantuansosial perspektif ekonomi islam",AL - Anwal,no. 2, vol 10,(2018), hal 217-221.

9 bid

10 Amirus sodiq, "konsep kesejahteraan dalam islam",equilibrium jurnal ekonomi syariah, no.2, volume 3 (Desenber,2015), 391.

11 Leo Agustino, Dasar-dasar Kebijakan Publik (Cet. 2; Bandung: Alfabeta, 2008), h. 7.
} 
Kesejahteraan sosial yang digambarkan Al-Qur'an tercermin dari surga yang dihuni oleh adam dan istrinya, sesaat sebelum turunnya mereka menjalankan tugas kekhalifahan di muka bumi. Keadaan adam dan isrinya di surga merupakan bayang-bayang impian manusia akan kehidupan yang nyaman, tercukupinya pangan, sandang dan papan, dalam artian tidak kelaparan, dahaga, telanjang, dan kepanasan. Tercukupinya kebutuhan adam selama di Surga merupakan unsur pertama dan utama kesejahteraan sosial.

Keadaan Nabi Adam dan istrinya yang tercukupi kesejahteraan sosialnya selama di Surga dapat kita lihat dalam firman Allah surat Thaha ayat 117-119.

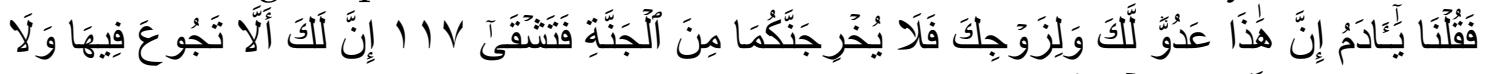

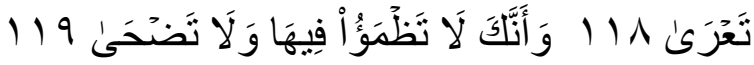

Terjemahan: "kemudian kami berfirman, "wahai adam, sesungguhnya ini (iblis) adlah musuh bagimu dan bagi istrimu, maka sekali-kali jangan sampai ia mengeluarkan kamu berdua dari surga, nanti kamu celaka. Sungguh, ada jaminan untukmu di sana, engkau tidak akan kelaparan dan tidak akan telanjang. Dan sungguh, di sana engkau tidak akan merasa dahaga dan tidak akan di timpa panas matahari". (QS. Thaha:117-119)12

Berdasarakan ayata diatas, tergambar bahwa kehidupan di surga merupakan kehidupan yang aman, sentosa dan makmur. Kesejahteraan yang ada di Surga merupakan sesuatu yang telah ada karena diberikan oleh Allah sebagai karunia oleh penghuni Surga tanpa harus di usahakan, sedangkan kesejahteraan yang dibumi bukanlah sesuatu yang ada dengan sendirinya akan tetapi sesuatu yang harus diusahakan, dicari dan diperjuangkan untuk dimiliki dan dinikmati. Menurut Sayyid Qutb, sistem kesejahteraan sosial yang diajarkan oleh Islam bukan sekedar bantuan keuangan apapun bentuknya. Bantuan keuangan hanyalah satu dari sekian bentuk bantuan yang dianjurkan Islam.

\section{METODELOGI PENELTIAN}

\section{Jenis Penelitan}

Penelitian ini adalah penelitian deskriptif menggunakan pendekatan kualitatif. Penelitian dengan menggunakan metode tersebut tidak mencari atau menjelaskan hubungan, tidak menguji hipotesis, atau membuat prediksi, akan tetapi menitik beratkan pada observasi dan suasana alamiah (naturalistis setting). ${ }^{13}$ Peneliti bertindak sebagai pengamat, peneliti hanya membuatkategoriperilaku, mengamati gejala, dan mencatat dalam buku

\footnotetext{
12Departemen Agama RI, Al Quran dan Terjemahnya (Semarang: Toha Putra 2002), h. 337

13Kartini Kartono, Pengantar Metodologi Riset Social (Bandung: Alumni, 1986), h. 28.
} 
observasi dengan suasana alamiah. Dimaksudkan bahwa peneliti terjun langsung ke lapangan. Peneliti tidak berusaha memanipulasi variabel. karena kehadirannya mungkin mempengaruhi perilaku gejala, peneliti berusaha mempengaruhi ini. ${ }^{14}$

Dalam pengumpulan sumber data, peneliti melakukan pengumpulam sumber data dalam wujud data primer dan data sekunder. Menurut sugiyono Data primer merupakan sumbar data yang langsung memberikan data kepada pengumpul data, sumber data primer didapatan melalui kegiatan wawancara dengan subjek penelitian dan dengan observasi atau pengamatan langsung dilapangan. ${ }^{15}$ Adapun pengumpulan data dalam penelitian uaitu dengan metode observasi, wawancara dan dokumentasi.

\section{HASIL DAN PEMBAHASAN}

\section{Penyajian Data}

Dampak Bantuan Langsung Tunai (BLT) Dana Desa Terhadap Kesejahteraan Masyarakat Desa Oi Tui Pada Masa Pandemi COVID-19 di Tinjau Dari Perspektif Ekonomi Syariah.

Berdasarkan hasil wawancara dengan salah satu keluarga penerima manfaat (KPM) BLT Dana Desa di kediamannya, terkait dampak BLT Dana Desa dalam meningkatkan kesejahteraan keluarganya yaitu Ikraman beliau berpendapat bahwa.

"Program BLT Dana desa memang bagus dan membantu masyarakat di Desa Oi Tui saat ini, terutama untuk memenuhi kebutuhan pokok dan kebutuhan lainnya. Akan tetapi jika ditanya apakah BLT berdampak pada peningkatan kesejahteraan masyarakat di Desa Oi Tui, tentunya berdasarkan pada apa yang saya rasakan sehari-hari tidak ada peningkatan kualitas hidup apalagi peningkatan kesejahteraan bagi saya. ${ }^{16}$

Berdasarkan hasil observasi yang dilakukan peneliti ada beberapa indikator yang menyebabkan uang BLT ini tidak begitu berdampak pada peningkatan kesejahteraan masyarakat di Desa Oi Tui yaitu:

1. Nominal uang yang diterima masyarakat setiap bulannya terlalu kecil.

2. Pembagian BLT tidak dilakukan secara teratur setiap bulan seperti regulasi dari pemerintah pusat seperti yang dilaksanakan desa-desa lain.

3. Jumlah keluarga penerima manfaat (KPM) yang sedikit pada tahun anggaran 2021.

4. Pos anggaran dana desa untuk BLT yang kurang. ${ }^{17}$

${ }^{14}$ Syofian Siregar, Statistik Deskriptif untuk Penelitian (Jakarta: Rajawali Pers, 2012), h

15Sugiyono, metode penelitian manajemen,(Bandung: Alfabeta 2014) h. 142.

16.Ikraman, selaku KPM BLT, wawancara, Oi Tui, 20 Juli 2021.

17Observasi oleh peneliti di Desa Oi Tui, 21 Juli 2021. 
Hal ini di benarkan oleh Dahlan Basri aparat Desa lainnya, beliau adalah kasi pelayanan membeberkan:

"Uang BLT Dana desa yang diterima Selama 12 bulan sebesar Rp. 300.000 tiap bulan dan dibagi dalam 2 tahap ini belum mampu meningkatkan kesejahteraan masyarakat kami sebagai masyarakat miskin. Karena uang itu hanya cukup untuk belanja kebutuhan sehari-hari. Itupun tidak cukup untuk satu bulan, apalagi bagi keluarga yang banyak tanggungannya. Jadi susah bagi masyarakat untuk memperbaiki ekonomi dengan uang itu. ${ }^{18}$

Dapat dianalisa bahwa Bantuan Langsung Tunai (BLT) Dana Desa memang tidak secara langsung berdampak pada meningkatnya daya beli masyarakat miskin yang ada di Desa Oi Tui, namun program itu membawa mannfaat bagi mereka.

\section{Peran Pemerintah Desa dalam Pelaksanaan Penyaluran Program BLT Dana Desa di Desa Oi Tui.}

Pemerintah desa sangat berperan penting dan wajib dalam menjalankan dan menyalurankan BLT Dana Desa. Berdasarkan hasil wawancara dengan Kepala Desa Oi Tui bapak Sudirman, beliau menuturkan:

"Wajib bagi kami menganggarkan dan melaksanakan kegiatan BLT Dana Desa ini sesuai pada PMK Nomor 222 pasal 39 ayat 1, disebutkan pemerintah desa wajib menganggarkan dan melaksanakan BLT Dana desa, BLT Dana desa menjadi perioritas utama dalam penggunaan Dana desa tahun 2021 ini, pembangunan fisik hanya beberapa saja yang kami lakukan seperti pengadaan lampu jalan. Maka dalam hal ini kami menetapkan perdes mengenai: penetapan jumlah KPM tahun 2021, atau Tidak terdapat penyaluran BLT Dana Desa apabila tidak terdapat calon KPM BLT Dana desa yang memenuhi kriteria, selanjutnya kami Melaporkan realisasi penyaluran BLT Dana desa, dan Penetapan kriteria keluarga penerima manfaat (KPM)."19

Dengan diwajibkannya penganggaran dan pelaksanaan BLT Dana Desa, tentu ada sanksi-sanksi yang dikenakan bagi pemerintah desa yang tidak melaksanakan peraturan tersebut. Dalam hal ini beberapa sanksi yang dikenakan kepada pemerintah desa sebagaimana hasil wawancara dengan bapak Saifullah selaku pendamping desa beliau menuturkan.

"Iya ada beberapa sanksi yang memang akan dikenakan untuk pemerintah desa yang tidak melaksanakan BLT Dana desa, sebagaimana tertuang dalam permenkeu nomor 222/PMK.07/2020. Dalam pasal 55 dan 56 berturut-turut disebutkan akan ada pemotongan Dana desa 50\% dari Dana desa yang akan disalurkan pada tahap II Tahun anggaran 2021 bagi Desa

${ }^{18}$ Dahlan Basri, aparat Desa, wawancara, Oi Tui, 20 Juli 2021

19Sudirman, Kepala Desa, wawancara, Oi Tui, 23 Juli 2021. 
yang tidak menyalurka BLT Dana desa sampai tahap 9 (Desember) Tahun 2020." 20

Sekretaris Desa dalam Hal ini Pak Farhan ketika diwawancarai terkai peran pemerintah Desa dalam pelaksanaan penyaluran BLT Dana Desa di Desa Oi Tui, beliau menjelaskan:

“Dalam hal pelaksanaan dan penyaluran BLT ini kami dituntut benarbenar bekerja sangat ekstra dan hati-hati agar sesuai dengan regulasi yang sudah ditetapkan oleh pemerintah pusat, walaupun ada beberapa kelalaian terkait surat edaran dalam pelaksanaa BLT ini dan tentunya pemerintah desa dalam hal ini akan melakukan evaluasi lagi. Beberapa persoalan dalam penyaluran BLT; Pertama, pemerintah desa terkadang bertentangan dengan aturan yang menginstruksikan dengan dilarang berkerumun pada saat pembagian BLT agar tidak terjadi penularan COVID-19, walaupun di desa Oi Tui tidak ada warga yg terjangkit. Kedua, pembagian pada dasarnya dilakukan per dusun, akan tetapi untuk menghindari polemik seperti tahun 2020 lalu maka pemerintah desa membagikan BLT tersebut di kantor desa. Ketiga, instruksi pemerintah pusat bahwa masyarakat penerima manfaat harus yang sudah di Vaksin, akan tetapi faktanya masyarakat penerima manfaat banyak yang belum di vaksin. Keempat, terjadi mis komunikasi dengan masyarakat terkait hari pembagian BLT, dan penetapan daftar KPM. Kelima, terlambatnya pencairan anggaran dana desa sehingga penyelenggaraan BLT Dana Desa sedikit terlambat dari yang seharusnya awal tahun 2021 sehingga program BLT ini dianggarka di pertengan tahun $2021 .{ }^{21}$

\section{Analisis Data Dan Pembahasan}

Dampak Bantuan Langsung Tunai (BLT) Dana Desa Terhadap Kesejahteraan Masyarakat Desa Oi Tui Pada Masa Pandemi COVID-19 Ditinjau dari Perspektif Ekonomi Syariah.

Jika dianalisa semua informasi yang diperoleh dari hasil wawancara terhadap informan bahwa penggunaan Bantuan Langsung Tunai Dana desa memang dipakai untuk memenuhi kebutuhan mendasar. Karena jumlah uang yang diterima Keluarga Penerima Manfaat (KPM) minim dan tidak memungkinkan dipakai untuk pengembangan usaha ataupun peningkatan kualitas hidup.

20Saifullah, selaku pendamping Desa, wawancara, Wera, 8 Oktober 2021.

${ }^{21}$ Muhammad Farhan, Sekretaris Desa, Wawancara, Oi Tui, 23 Juli 2021. 
Berdasarkan penuturan dari sebagian besar KPM BLT dana desa tersebut jelas bahwa bantuan memang sangat dibutuhkan oleh masyarakat miskin di Desa Oi Tui untuk dapat membantu agar dapat bertahan hidup dan menambah pendapatan, sehingga masyarakat miskin tidak menjadi semakin miskin. Dalam hal ini juga ada masalah lain yang penting untuk disoroti adalah pada jumlah Bantuan Langsung Tuna tersebut, yaitui sebesar Rp 300.000/KPM yang diterima setiap bulan penerimaan. Angka itu dinilai sangat kecil jika dilihat dari kebutuhan masyarakat saat ini. Islam menganjurkan untuk memberikan bantuan untuk mewujudkan keseimbangan ekonomi dan juga tanggung jawab pemerintah untuk kesejahteraan masyarakatnya.

\section{Peran Pemerintah Desa dalam Penyaluran Program BLT Dana Desa di Desa Oi} Tui.

Pemerintah Desa Oi Tui telah menjalani aturan hukum yang telah di tetapkan mengenai penyaluran Bantuan Langsung Tunai (BLT) Dana Desa. Karena dalam aturan tersebut menjelaskan tentang kriteria masyarkat yang berhak menerima BLT Dana Desa ini. Pemerintah Desa juga di tuntut untuk bisa menjalankan aturan yang telah di amanatkan oleh pemerintah pusat untuk bisa menyalurkan Bantuan Langsung Tunai ini dengan baik, karena ini merupakan tanggung jawab oleh pemerintah daerah sampai ke pemerintah desa. Karena sesuai aturan yang berlaku, bahwa program ini dapat di jalankan dengan baik oleh pemerintah yang ada, guna bisa menjawab permasalahan ekonomi masyarakat di Desa Oi Tui pada saat ini.

\section{KESIMPULAN}

Berdasarkan hasil penelitian mengenai dampak Bantuan Langsung Tunai (BLT) Dana desa terhadap kesejahteraan masyarakat Desa Oi Tui pada masa pandemi COVID-19 ditinjau dari perspektif ekonomi syariah, maka dapat ditarik beberapa kesimpulan:

Bahwa penggunaan uang Bantuan Langsung Tunai (BLT) Dana desa memang hanya dipakai untuk memenuhi kebutuhan mendasar dari masyarakat Desa Oi Tui. Akan tetapi meskipun BLT belum mampu meningkatkan kesejahteraan hidup masyarakat desa Oi Tui namun Bantuan Langsung Tunai tersebut memiliki manfaat bagi kelangsungan hidup mereka terutama pada masa pandemi COVID-19 ini terutama untuk membeli sembako.

\section{DAFTAR PUSTAKA}

J-ESA (Jurnal Ekonomi Syariah) 
Amirus sodiq, "Konsep Kesejahteraan dalam Islam” equilibrium jurnal ekonomi syariah, no.2, volume 3 (Desenber,2015)

Carly Erfly Fernando Maun, "Efektivitas Bantuan Langsung Tunai Dana desa bagi Masyarakat Miskin Terkena Dampak Covid-19 Di Desa Talaitad Kecamatan SuluunTaretan Kabupaten Minahasa Selatan".Jurnal politic,.No. 9., volume 2 ( 2020), 1-2.

Departemen Agama RI, Al Quran dan Terjemahnya (Semarang: Toha Putra 2002)

Fatkhul Khoiriyah dkk, "Efektivitas Pelaksanaan Bantuan Sosial Dari Pemerintah Terhadap Masyarakat Terdampak COVID-19 di Desa Gendongarum Kecamatan Kanor Kabupaten Bojonegoro,"spirit public, no.2 volume 15, (2020)

Kartini Kartono, Pengantar Metodologi Riset Sosial (Bandung: Alumni, 1986)

Leo Agustino, Dasar-dasar Kebijakan Publik, Cet. 2 (Bandung: Alfabeta, 2008)

Rudi S. prawiradinata, Panduan Pendataan Bantuan Langsung Tunai Dana Desa

(BLT dana desa), (Jakarta: Kementerian Desa, Pembangunan Daerah Tertinggal Dan Transmigrasi, 2020)

Sugiyono, Metode Penelitian Manajemen, (Bandung: Alfabeta 2014)

Syekh nurjati, "Peranan Pemerintahdalammensejahterakanmasyarakat Melalui Bantuansosial Perspektif Ekonomi Islam",AL - Anwal, no. 2, volume 10, (2018)

Syofian Siregar, Statistik Deskriptif untuk Penelitian (Jakarta: Rajawali Pers, 2012) 